\title{
О литературе как феномене эстетики
}

\author{
Михайло Наєнко, Художня література Украӥни. \\ Від міфів до модерної реальності, \\ Видавничий Центр „Просвіта”, Київ 2012, 1088 с.
}

Сравнительно недавно, в конце 80-х - начале 90-х годов прошлого века, мы были не только свидетелями, но и участниками весьма неожиданной дискуссии: нужна ли нам история литературы, по крайней мере, как детище академического литературоведения? Ее инициаторы поставили под сомнение даже те „истории”, в которых излагались авторские курсы лекций. Дискуссия обещала быть острой, поскольку намеревалась вытеснить тягостное советское наследие, которое выражалось, среди прочего, в историческом подходе к литературному процессу. Такой шаг расценивался как возможность радикального обновления методологических основ науки. Впрочем, зарубежные ученые, к которым почтительно апеллировали отечественные новаторы, придерживались классических позиций, имея в своем арсенале многотомные работы по истории национальных литератур, что было характерно не только для литератур с мощными вековыми традициями, например, английской, французской, немецкой, но и для так называемых „молодых", для которых наличие истории было весомой формой утверждения себя в мире. Вопреки ожиданиям дискуссия протекала вяло, была почти бездыханной и, наконец, прекратилась так же внезапно, как и началась, оставив поставленные вопросы без ответа.

Не внесли ясности и исследования последующих десятилетий, каждое из которых демонстрирует авторский взгляд на определенный период развития литературы, творческую личность и результаты её труда с позиций отдельных литературоведческих подходов. Деление 
литературы на „актуальные” проблемы/эпохи (модернизм, постмодернизм) и „неактуальные” (реализм, литература „советской цивилизации") обусловило разорванность, разделённость эпох и в то же время продемонстрировало отсутствие научного диалога, подчеркнуло распыленность мыслей и взглядов, нивелируя значимость мысли об украинской литературной целостности. Избирательность, классовый подход к истории литературы, в чём справедливо обвиняли советское литературоведение, не сдавали свои позиции и в этот период. Теперь всё происходило с точностью до наоборот: исследователи принялись клеймить писателей и их творения только за то, что произведения или их авторы имели какое-либо отношение к советской парадигме, тем самым оголяя, обедняя культурное наследие, создававшееся десятилетиями.

Ошибочность такого подхода становилась всё более очевидной. Все острее ощущалась потребность в создании истории литературы и как фона, на котором любые исследования приобретали бы глубину и перспективу, и в её академическом варианте (проект был предложен сотрудниками Института литературы НАН Украины им. Т.Г. Шевченко), и в так называёмом „университетском” формате - как опыта индивидуального лекционного курса (известно множество таких изданий). Однако и эти варианты далеко не во всем удовлетворяли современные запросы. Назрела потребность в издании, которое отличалось бы и по содержанию, и по форме. Такая книга была создана. Её название - Xyдожественная литература Украины. От мифов до модерной реальности, автор - Михаил Кузьмич Наенко - известный ученый, теоретик и историк литературы, лауреат Национальной премии им. Т.Г. Шевченко, чье научное творчество охватило вторую половину ХХ столетия и проросло в XXI век.

Наенко известен многочисленными работами (более 500). Его Художественная литература Украины является результатом кропотливого многолетнего труда, который засвидетельствовал и для филологического сообщества, и для студенческой аудитории, и для рядового читателя, интересующегося историей культуры, синтез авторства и авторитета, высокой академичности и современного литературоведческого мышления. В концептуальном формировании истории украинской литературы мнение и влияние этого ученого были едва ли не наиболее 
значимыми. Много ли мы знаем подобных примеров в литературоведении современности? Признаем, что это единичные, но не случаи, а закономерности, поскольку всегда, во все времена были ученые-лидеры, чьи идеи вдохновляли, побуждали к научному творчеству, открывали новые направления, которые получали развитие в отечественных и зарубежных исследованиях. Михаил Наенко принадлежит именно к такой когорте, к числу тех, кого называют „пророками своего дела" - филологии, в которой разворачиваются едва ли не наиболее жаркие бои за „историю” как таковую, а также историю языка, литературы, искусства, культуры в целом. Он наш современник и ощущает на себе весь драматизм и трудности бытия в эпоху перемен, которые особенно ярко проявляются в идеологической сфере. Отсюда такая глубоко осознанная, без лишнего пафоса, мысль, что история - государства, культуры, литературы (понятия одного ряда) - это духовное богатство народа, нации. Вот почему с таким творческим размахом и настойчивостью писалась, дополнялась и издавалась эта книга (она выходила трижды, и большая часть тиражей осела в домашних библиотеках).

Что же касается изданий, это также особая страница нашего литературоведческого настоящего, поскольку не так много в Украине ученых, тиражи книг которых растут и расходятся на удивление быстро. Филологическая общественность уже почувствовала усталость от „игры в науку”, читатели - от „игры в литературу”. Стремление вернуться к научной классике, учитывающей современные требования, и в то же время к авторитетным суждениям, от которых не так давно отрекались, назрело. И личностей, взявших на себя ответственность сказать новое слово, не так и много. Михаил Наенко - один из них. При любой власти его взвешенное мнение оказывалось авторитетной поддержкой в творческих поисках для нескольких поколений ученых, многих из которых он воспитал как своих единомышленников.

Книга Художественная литература Украины имеет массу преимуществ по сравнению с другими изданиями историко-литературного характера. Как известно, Наенко является автором многих академических изданий истории литературы, мастерски владеет высоким научным стилем, унаследованным от Владимира Перетца, Димитрия Чижевского, Алєксандра Белецкого, сочетая классические подходы с требованиями современности; ученый предложил историю украинской литературы 
от древности до настоящего момента, явленную не многотомным изданием, а однотомным - объемной, емкой, информационно насыщенной книгой с индивидуальным взглядом на литературные явления, изложенные доказательно и оригинально. Автор не имел намерения дать будничный исторический очерк, состоящий из перечня фактов разного уровня важности и совмещенный с более или менее обособленными литературными портретами отдельных писателей, а стремился отследить условия, закономерности и факторы формирования важных этапов эволюции главных литературных направлений в национальной модификации, самой литературы от мифов до „модерной реальности” в единстве и своеобразии, без мельчайшего намёка на национальную изолированность. В исторической интерпретации Наенко украинская литература предстает как целостность, эстетически открытая для взаимовлияния и взаимодействия.

Книга явила живую историко-литературную цепь, дух которой освящен целостным образом украинской словесности, атмосферическим присутствием её персоналий и судеб (так отметил когда-то Николая Гоголь значимость Василия Жуковского, к мысли которого невольно возвращаемся благодаря её меткости и ёмкости). Учитывая требования времени, которые сочетались с внутренней потребностью к открытому общению с читательской аудиторией, учёный избрал наиболее подходящую в этой исторической ситуации форму общения - диалогическую, ведь предшествующий контекст восприятия „истории” уже сам стал историей; изменился не только фон, атмосфера отношения к происходящему (настороженность, иногда граничащая с циничностью), но и то, что целесообразно обозначить как „презумпцию понимания”, с позиции которой современный читатель (профессионал или так называемый „массовый”, но интересующийся уже не только детективом) подойдёт к книге со своими определенными суждениями. Наенко даёт возможность открыть ранее неизвестное, поэтому книгу выбирают, ориентируясь на имя автора и авторитетность его суждений, умение приобщить к высоким размышлениям. Форма диалога сделала возможным непринужденное общение, известное со времен античности, когда о философии и филологии говорили доступно и в то же время с научной значимостью. С такой непринужденностью Наенко и предложил свою классическую методологию - разговор об эстетике литературы 
не как о синониме „красивости”, а как о философии художественного мира писателя, или, по определению Гегеля, - „философии искусства” либо, более определённо, „философии художественного творчества”.

Если условно классифицировать написанные истории украинской литературы по степени сложности, то предложенная Наенко история в аспекте эстетики литературы займёт одно из первых мест. С таких позиций об украинской литературе ещё не писали. Именно поэтому Наенко нигде не декларирует, что это учебник (хотя преподаватели и студенты воспринимают книгу именно так) или история литературы, поскольку внимание автора сосредоточено, по его же словам, на вещах и событиях „эстетически ценных”, но историко-литературный пласт в работе всё же необычайно мощный. Своё творение Наенко определил как Книгу, вкладывая в это понятие глубочайший культурный смысл, созвучный с воззрениями XXI века, особенно когда Автор, один из наиболее известных создателей историко-литературных трудов, отказывается от обременительной академичности и непринужденно предлагает „договориться” о наиболее сущностном - о методологии (а не навязать её!). Это очень созвучно с мнением Лиотара, который считает, что поскольку наука не ограничивается исключительно формулированием инструментальных закономерностей, а ищет истину, она должна легитимизировать свои правила игры. И это не единичный случай. Одной из особенностей научной деятельности Наенко является ориентированность на диалог с другими культурами, литературами, научными концепциями. Напомним в связи с этим фразу из программной статьи Сєргєя Аверинцева Филология (1972), в которой, рассматривая историю филологии, ученый выражал сожаление по поводу утраты „интимности отношения к предмету”. Отклик на эту мысль прозвучал значительно позднее, в тот исторический момент, когда формализация филологических знаний достигла угрожающих размеров. Именно тогда и появилась работа Наенко с интригующим названием Интим писательского труда, в которой он продемонстрировал своё умение „войти внутрь” творческого процесса, что далеко не всем удается (на этом и делал акцент Аверинцев, апеллируя к тем, кто может откликнуться на его призыв). В Художественной литературе Украины нашла воплощение не менее важная мысль всемирно известного ученого - об интимном „воспитании чувств”, которое Наенко 
непосредственно связывает с украинской литературой как бесценным достоянием народа.

В книге ученый продемонстрировал уникальную способность выявлять сложную по своей сути и необычайно динамичную в своём развитии взаимосвязь народно-национальных основ и литературного мышления, раскрытую в обстоятельно обоснованной системе; представление о литературе как феномене эстетики, явленном через „Плеяду индивидуальных стилей”, сгруппированных в „стилевые эпохи” и осмысленных при помощи соответствующих историко-филологических методов, совокупность которых составляет „центр эстетического анализа литературы". Он предлагает различать в выстроенной им синонимике родственные, близкие по смыслу литературоведческие явления: „эстетика литературы”, „эстетика произведения”, „эстетический анализ литературы”, „эстетические критерии”, „эстетически ценное” - и все это на основании эстетичности, которая интерпретируется как „всеохопна, універсальна і єдина суть мистецької, зокрема й літературної, творчості”' (с. 5). Формы же проявления эстетики автор видит „в мотивах, сюжетах, конфликтах” (с. 4). Именно так, без излишней аффектации, идеологизации или политизации Наенко в присущей ему манере сочетания высоких научных размышлений с наболевшими вопросами современности, в частности с языковым вопросом, отмечает: „Коли говорять, що „естетика твору - це насамперед чарівна мова його, то маються на увазі саме стильові ознаки твору”2 (с. 4). „Эстетически ценное” исследователь одевает в „эстетическое убранство”, которым является „художественный стиль”. Таким образом, Наенко актуализировал для иногда весьма прихотливой сегодня литературоведческой сферы классическое понятие ,художественная литература” и методику, ему адекватную, - эстетику произведения и художественный стиль, в последние годы отодвинутые на второй план разного рода терминологическими новациями. В связи с этим возникают параллели с позицией Юрия Лотмана - с тем, как известный ученый, отдавая должное

1 Всеохватывающая, универсальная и единственная суть художественного, в частности литературного, творчества.

2 Когда говорят, что „эстетика произведения - это прежде всего прекрасный язык его”, то имеют в виду именно стилевые особенности произведения. 
литературоведческим новациям, в разгаре собственных структуралистских увлечений, беспокоился о „смысле самого понятия «литература»” как „точке зрения” на изложение „общеизвестных фактов литературной истории" его любимого XVIII века.

Художественная литература Украины дифференцирована на разделы-эпохи, содержащие ёмкую и выразительную характеристику украинской мифологии и фольклора с акцентом на переходе к собственно литературе с её эпохальной содержательностью монументализма, орнаментализма, ренессанса, барокко, классицизма, реализма, романтизма, постмодернизма. Каждое из этих явлений имеет чёткое определение и в аспекте связи с предшествующей традицией, и в перспективе дальнейшего развития, особенно через культуру нео- в XX и XXI вв. При этом определения не перегружены теоретизированием, а тесно связаны с детализированными наблюдениями за поэтологическими принципами того или иного направления или творчества отдельных писателей. В этом состоит очевидное преимущество однотомника, поскольку в многотомных изданиях такие связи сложно выводить и удерживать. Наенко в присущей ему виртуозной стилевой манере, сочетающей интеллект и непринужденность изложения, легко устанавливает связи между эпохами, анализирует украинские творческие достижения особым способом, который дает возможность выстроить определенные „мосты” между направлениями и течениями, связать в единую концептуальную цепь не только литературные явления переходного характера (например ранний модернизм или авангард 20-х годов), но и украинский литературный процесс в целом в его непрерывности и преемственности одновременно.

Автор продемонстрировал оригинальный анализ ряда „-измов” не только как литературных явлений, но - шире - художественных (особенно барокко, импрессионизма), а иногда - жизненных, которые переходят в эстетизированный быт. Такой тип анализа необычайно важен, поскольку позволяет систематизировать знания о разных сферах литературы и искусства, увидеть за отдельными фактами не хаос деталей, а своеобразную систему художественной жизни эпохи. Голос Автора, отшлифованный многолетней работой в аудитории, с большой выразительностью описывает трагические страницы истории литературы, сдержанно их комментирует, даже слёгка 
иронизирует. А предложенные вопросы к разделам-эпохам побуждают к размышлениям.

Есть ещё один важный аспект, который хотелось бы прокомментировать, - название книги. Увлечение современным литературоведением, понимание и толкование литературы как текста целесообразно, но при условии применения соответствующих методик. В исследованиях историко-литературного характера ключевым является понятие „художественная литература", которое Наенко актуализирует для современников, нюансируя его гегелевский смысл - как вид словесности, где на первом плане сугубо содержательное, духовное своеобразие, приумноженное её (художественной литературы) значениями XX века как творческой деятельности, одной из форм художественного освоения мира.

Название книги содержит и подзаголовок - От мифов к модерной реальности. Безусловно, у многих читателей возникает вопрос: почему в подзаголовок вынесено не понятие модерна, а словосочетание „модерная реальность”? Как известно, утвержденное европейским научным сообществом понятие модерн адекватно на восточнославянские языки так и не переведено. Здесь целесообразно присоединиться к мысли тех учёных, которые усматривают в этом проблему не понятийную, а ментальную: „модерн”, или „современность”, или, как у Наенко, модерная, то есть современная, реальность, являет собой историческое пространство, с которым себя идентифицирует и художественная литература, и творческая личность, ее репрезентирующая.

Ценность и значимость Художественной литературы Украины необычайно велика, поскольку в ситуации постмодерна историческое знание как таковое, и филологическое в частности, очень востребовано и социумом, и индивидуумом, который, в отличие от предшествующих культурных эпох, стремится не столько творить новую литературную реальность, сколько, пока что, ориентироваться в её бурном потоке. Книга Наенко предлагает эти ориентиры ненавязчиво, но взвешенно, как опыт авторитетного ученого, и уже воспринята как неординарное явление гуманитарной науки, в котором ощущается творческая мысль, высокий интеллект и несравненные познания о нашей литературной истории. 